J. Braz. Chem. Soc., Vol. 18, No. 5, 984-989, 2007.

Printed in Brazil - (C2007 Sociedade Brasileira de Química

$0103-5053 \$ 6.00+0.00$

\title{
Characterization of Woody Odorant Contributors in Copaiba Oil (Copaifera multijuga Hayne)
}

\author{
Beatriz M. P. Sant'Anna, Silvia Paredes Fontes, Angelo C. Pinto and Claudia M. Rezende* \\ Instituto de Química, Universidade Federal do Rio de Janeiro, Centro de Tecnologia, Bloco A, \\ Cidade Universitária, Ilha do Fundão, 21945-970 Rio de Janeiro-RJ, Brazil
}

\begin{abstract}
Copaifera multijuga Hayne é uma das espécies do gênero Copaifera da qual se extrai o óleo de copaíba. Além do uso como antiinflamatório e anti-séptico, o óleo de copaíba é utilizado na indústria de fragrâncias como fixador para perfumes, cosméticos e sabões. A fim de identificar as substâncias ativas no aroma do óleo de C. multijuga, CG-O-EM utilizando AEDA foi aplicada após a quantificação dos compostos por CG-DIC. Os resultados obtidos apontaram para $\delta$-cadineno (1,9\%, FD 64), $\delta$-cadinol (0,9\%, FD 128), óxido de cariofileno (0,2\%, FD 64), (Z)$\alpha$-santalol (0,2\%, FD 128), $\alpha$-cadinol $(0,1 \%$, FD 128$)$ e $\tau$-muurolol $(0,1 \%$, FD 128$)$ como as substâncias de odor mais ativo no aroma deste óleo de copaíba. Quanto à contribuição aromática dos enanciômeros do $\delta$-cadineno analisada por CG-EM-O-quiral, somente o enanciômero (+)$\delta$-cadineno foi encontrado no óleo e apresentou aroma adocicado, verde e refrescante.
\end{abstract}

Copaifera multijuga Hayne is one of the Copaifera species from which copaiba oil is extracted. Employed in the composition of anti-inflammatory and antiseptic products used in phytotherapy, it is also used by the fragrance industry as a fixative in perfumes, cosmetics and in products such as soaps. To identify the active aroma compounds in C. multijuga oil bouquet, GC-O-MS using AEDA (Aroma Extract Dilution Analysis) was used after the quantification of the components by GC-FID. The results obtained pointed to minor compounds such as $\delta$-cadinene $(1.9 \%$, FD 64$), \delta$-cadinol $(0.9 \%$, FD 128$),(Z)-\alpha$-santalol $(0.2 \%$, FD 128$)$ caryophyllene oxide $(0.2 \%$, FD 64$), \alpha$-cadinol $(0.1 \%$, FD 128$)$ and $\tau$-muurolol $(0.1 \%$, FD 128$)$ as the most intense compounds in the odor of the copaiba oil studied. Chiral GC-O-MS showed (+)- $\delta$-cadinene as the only enantiomer present in the oil, with a sweet, green and refreshing aroma.

Keywords: Copaifera multijuga Hayne, copaiba oil, gas chromatography-olfatometry-mass spectrometry, AEDA, quiral GC, sesquiterpene

\section{Introduction}

Copaifera multijuga Hayne is mainly found in the Central and Oriental Amazon ${ }^{1}$ and is one of the most common species for the extraction of copaiba oil. ${ }^{2}$ This oil is usually a transparent liquid, whose color varies from yellow to brown and actually it is an oleoresin, due to its content of diterpenic acids and great amounts of sesquiterpenes. ${ }^{3-5}$ Copaiba oil is well-known by its pharmacological activities (i.e. antitumoral; antiinflammatory and antiseptic) and is also used in cosmetics and as varnish in paintings. ${ }^{1,6,7}$

According to the most recent silviculture data published by the Brazilian Institute of Geography and Statistics (IBGE), the search for this raw material has been growing. In 2001 the extraction of copaiba oil corres-

*e-mail: crezende@iq.ufrj.br ponded to 414 ton, while from 1974 to 1979 the quantity of the oil produced in Amazon was 200 ton/year. ${ }^{8,9}$

Different from Europe, Brazil doesn't have a fragrance industry tradition. The Brazilian market has been increasing and, in 2004, the industry of cosmetics, toiletries and fragrance showed an increment of $36.1 \%$ in exports in comparison with the year before, and a sales growth of US\$ 4.5 billion. ${ }^{10}$ As a consequence, new products are necessary to enhance this growing demand. The woody and fixative aroma of copaiba oil has raised the interest of the perfume industry, always in need of innovative ingredients. ${ }^{10-13}$ However, because of its already consolidated therapeutic effects, the composition of the copaiba oil odor has been neglected and despite its fragrant value, little information regarding its odorant potential is available in the literature.

To broaden even more the application range of copaiba oils, this is the first approach to be published 
concerning its aroma. The technique chosen to develop this research was AEDA (Aroma Extraction Dilution Analysis), a dilution technique of Olfatometry (GC-O) based on consecutive dilutions of the original sample. ${ }^{14}$ According to this method, substances detected at the lowest dilutions are the aroma active ones and are known as impact aroma compounds. Each aroma compound is referred with a FD factor (or the last dilution at which the odor active compound is detected). ${ }^{15-19}$ The analyses were supported by GC-OMS (Gas Chromatography-Olfatometry-Mass Spectrometry) $)^{12,20}$ associated with standard co-injection and olfatometric evaluations together with retention indice calculations. ${ }^{21}$

\section{Experimental}

\section{Copaiba oleoresin}

Crude copaiba oleoresin was obtained as an exudate of Copaifera multijuga Hayne, directly collected from perforation of a tree trunk in Ducke Reserve, Central Amazon, in 2001. The copaiba oleoresin was kindly donated by the Instituto Nacional de Pesquisas da Amazônia (INPA).

For GC studies, $60 \mathrm{mg}$ of the sample were diluted in 1 $\mathrm{mL}$ of hexane (Tédia, Brazil) and methylated with a diazomethane ethereal solution to convert the diterpenic acids into methyl esters, reducing their interaction with the stationary phase and, as a result, improving chromatographic resolution.

$G C-M S$

Qualitative analysis was performed in Agilent Technologies 6890N Network GC Systems (Avondale, PA, USA) and Agilent 5973 Network Mass Selective Detector (Avondale, PA, USA) with electron impact at $70 \mathrm{eV}$, equipped with a BP-5 fused silica capillary column (25 m $\times 0.22 \mathrm{~mm} \times 0.25 \mu \mathrm{m}$; SGE 25AQ2, Austin, USA). The scan rate was $2.89 \mathrm{~s}^{-1}$, the transfer line and ionizing source were both maintained at $280{ }^{\circ} \mathrm{C}$. The initial oven temperature was held at $30^{\circ} \mathrm{C}$ for $1 \mathrm{~min}$, increased at $50{ }^{\circ} \mathrm{C} \min ^{-1}$ to $105^{\circ} \mathrm{C}$, then at $1.5^{\circ} \mathrm{C} \min ^{-1}$ to $150{ }^{\circ} \mathrm{C}$ and finally at $30^{\circ} \mathrm{C} \mathrm{min}^{-1}$ to $280{ }^{\circ} \mathrm{C}(10 \mathrm{~min})$. The injection port, in splitless mode for 1 min was at $270{ }^{\circ} \mathrm{C}$ and $\mathrm{He}$ was used as carrier gas with a flow rate of $1 \mathrm{~mL}$ $\min ^{-1}$. Linear temperature programming retention indices were calculated using successive $n$-alkanes (from $n$ tridecane to $n$-hexadodecane) in the same abovementioned analytical conditions. Compound identi- fications were made by comparison with available reference standards, co-injection with marigold and basil essential oils, ${ }^{22}$ the NIST MS Search Program $(1.7,2000)$, mass fragmentation pattern and previously reported retention indices. ${ }^{7,23-25}$

\section{Quantification}

For this purpose, GC analyses were carried out using a HP-5890 (Avondale, PA, USA) equipped with a flame ionization detector (FID) at $270{ }^{\circ} \mathrm{C}$ and a BP-5 fused silica capillary column $(25 \mathrm{~m} \times 0.22 \mathrm{~mm} \times 0.25 \mu \mathrm{m}$; SGE 25AQ2, Austin, USA). The same oven temperature program described in GC-MS analyses was employed. The injection port, in splitless mode for $1 \mathrm{~min}$, was kept at $270{ }^{\circ} \mathrm{C} . \mathrm{H}_{2}$ was used as carrier gas with a flow rate of 1 $\mathrm{mL} \min ^{-1}$.

$n$-Heptadecane $(0.15 \mathrm{mg}$, Aldrich) and $n$-pentadecanoyl propanoate $(1.5 \mathrm{mg}$, obtained by the reaction of $n$-pentadecanoyl chloride (Aldrich) with $n$-propanol in pyridine (Aldrich)) were used as internal standards, as two distinct regions, i.e., sesquiterpene hydrocarbons and diterpenic acids (as methyl esters) were observed. Both standards were added to $15 \mathrm{mg}$ of copaiba oil in dichlorometane (spectroscopic grade, Tédia, Brazil) after methylation of the oil with diazomethane and the solution was adjusted to $5.0 \mathrm{~mL}$ with dichloromethane in a volumetric flask.

The method precision was studied by two replicate analyses of the copaiba oil (two different solutions of the same oil were injected into GC-FID for two consecutive times). The precision was expressed by relative standard deviation (R.S.D.). The peak areas of the compounds were used for calculation of their R.S.D. values.

\section{GC-olfatometry}

Analyses were carried out using the above-described GC equipment, coupled to a stainless steel sniffing port held at $180{ }^{\circ} \mathrm{C}$. The oven temperature program and column conditions were also the same as mentioned for the quantification step. The GC effluent was split 1/10 between the FID and the sniffing port with a splitter tube. The mass spectrometer profile was compared with the olfatometry runs.

AEDA was performed by serial dilutions of the extract (1:1 v/v, dichloromethane spectroscopy grade) and sniffed twice by three assessors until no aroma could be perceived by any of the panelists. The results were expressed as a flavor dilution factor $(\mathrm{FD})=2^{\mathrm{n}-1}$, where $\mathrm{n}$ is the number of dilution (factor 2). 


\section{Sensory studies}

Five assessors were trained on descriptive and comparative techniques with known woody and amber compounds, in order to familiarize the participants with the woody attribute: ambroxide, $(Z)-(\beta)$-santalol, norambrenolide, trans- $\beta$-caryophyllene, cedrene, cedrol, $\alpha$-humulene, caryophyllene oxide and copaiba oils. None of the panelists were specifically anosmic to woody/ amber odor. Three volunteers, chosen according to their sensitivity and availability, performed AEDA evaluations.

\section{Statistical analysis}

Statistical analysis regarding the performance of the panelists was based on testing the hypothesis of equality of two proportions under independent sampling. ${ }^{26}$

\section{Isolation of $\delta$-cadinene from $C$. multijuga by GC trapping (micro fraction)}

$1 \mathrm{~m}$ of a $25 \mathrm{~m} \times 0.22 \mathrm{~mm} \times 0.25 \mu \mathrm{m} 5 \%$ phenylmethylpolysiloxane BP5 SGE (Austin, USA) fused silica capillary column was immersed on a $\mathrm{CO}_{2}$ /ethanol cold trap and connected to the sniffing port. At the retention time of $\delta$-cadinene the capillary tube was connected to the sniffing port and after four analyses, the contents of that piece of column were washed with $1 \mathrm{~mL} \mathrm{CH}_{2} \mathrm{Cl}_{2}$ into a vial (this solution is referred to as a micro fraction).

\section{Chiral GC analysis}

A J\&W Cyclodex B permethylated $\beta$-cyclodextrine (Folsom, CA, USA) capillary column $(30 \mathrm{~m} \times 0.25 \mu \mathrm{m}$ film x $0.25 \mathrm{~mm}$ ) was used to perform GC-O-MS in the aforementioned equipment. The GC-MS transfer line and the ionizing source were maintained at $210^{\circ} \mathrm{C}$. The oven program started from $50{ }^{\circ} \mathrm{C}(1 \mathrm{~min})$, increased at $10^{\circ} \mathrm{C}$ $\min ^{-1}$ to $100{ }^{\circ} \mathrm{C}$, then at $1.0{ }^{\circ} \mathrm{C} \min ^{-1}$ to $160{ }^{\circ} \mathrm{C}$ and finally at $30{ }^{\circ} \mathrm{C} \mathrm{min}$ mi $^{-1}$ to $210{ }^{\circ} \mathrm{C}$, held for $20 \mathrm{~min}$. Compound identifications were made by comparison with a reference standard of (-)- $\delta$-cadinene, ${ }^{27}$ fragmentation pattern and the NIST MS Search Program $(1.7,2000)$.

\section{Reference standards}

$(Z)-(\alpha)$-Santalol, $(Z)-(\beta)$-santalol, cedrene, cedrol, ambroxide and nor-ambrenolide were donated by International Flavors and Fragrances- IFF; trans$\beta$-caryophyllene, $\alpha$-humulene, caryophyllene oxide, copalic, ent-agathic, acetoxy-copalic and hydroxy-copalic acids were isolated in previous work of the $\operatorname{group}^{28}$ and $(-)-\delta$-cadinene was kindly offered by Dr. Margaret Essenberg (Biochemistry and Molecular Biology Department, Oklahoma State University).

\section{Results and Discussion}

Among the twenty-six compounds pointed out in the studied copaiba oleoresin by GC-MS, ten were identified by co-injection of standards, five by the co-injection with well-known essential oils [marigold (Calendula officinalis) and basil (Ocimum basilicum)] and the others were tentatively identified by mass spectrometry associated with linear retention indices calculations (Table 1; Figures 1A and 1B). Most of them were represented by sesquiterpene skeletons in agreement with previous reports on $C$. multijuga. ${ }^{6}$ Trans- $\beta$-caryophyllene was the major compound, followed by $\alpha$-humulene and $\beta$-bergamotene. From the acidic diterpenes, present in lesser amounts and identified by co-injection with previously isolated standards, ${ }^{28}$ copalic acid was the most abundant. The unknown compound $\mathbf{2 3}$ showed the same fragmentation pattern as the observed kolavenic acid methyl ester and possibly is a diastereoisomer of it, although no description of this isomer was found in literature. Different from other Copaifera species such
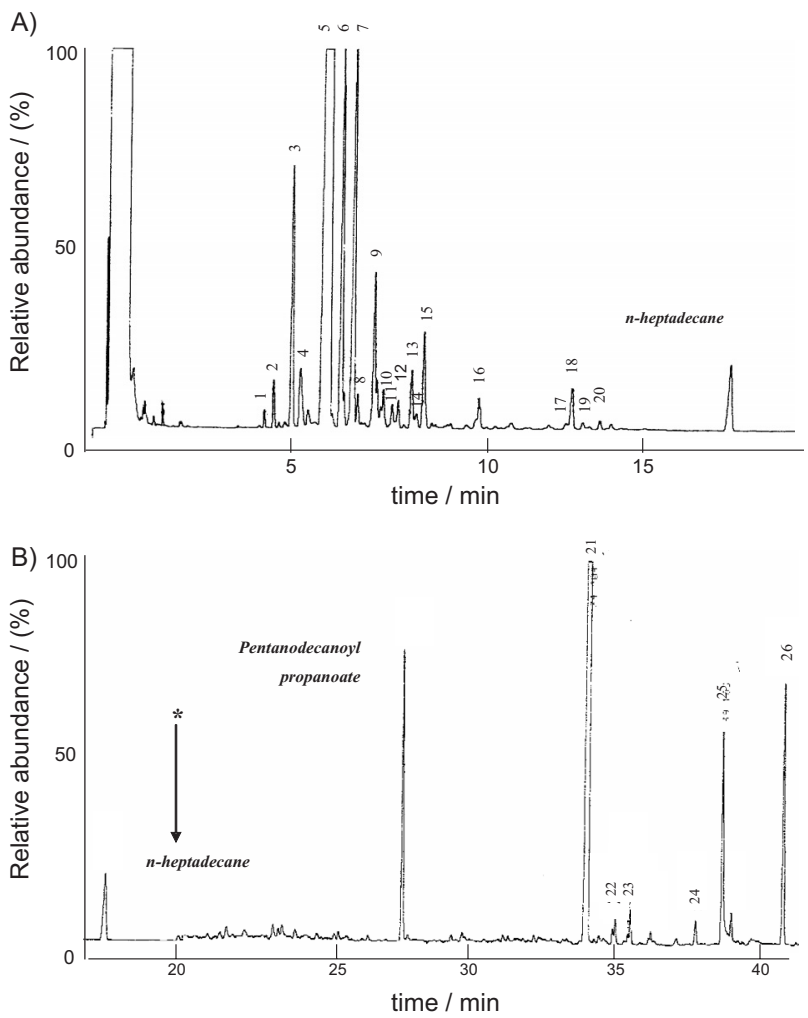

Figure 1. GC-MS of C. multijuga oleoresin. (A) Sesquiterpene region; (B) Diterpene region (*-attenuation changed from $2^{4}$ to $2^{1}$ to permit visualization of minor compounds). 
Table 1. Chemical composition and aroma profile of C. multijuga oleoresin

\begin{tabular}{|c|c|c|c|c|c|c|c|c|}
\hline Peak $^{a}$ & Compound & Conc./(mg L-1) & $\mathrm{RSD} /(\%)$ & $\mathrm{RI}^{\mathrm{b}}$ & $\mathrm{RI}_{\text {lit }}{ }^{7,23-27}$ & $(\%)$ & Odor(GC-O) & $\mathrm{FD}^{\mathrm{c}}$ \\
\hline 1 & $\alpha$-Elemene ${ }^{t}$ & 6 & 4.4 & 1344 & 1344 & 0.2 & Fresh & 2 \\
\hline 2 & $\alpha$-Cubebene ${ }^{t}$ & 16 & 5.5 & 1353 & 1351 & 0.6 & & \\
\hline 3 & $\alpha$-Copaene ${ }^{e}$ & 113 & 4.8 & 1380 & 1376 & 4.2 & Woody & 2 \\
\hline 4 & $\beta$-Cubebene ${ }^{t}$ & 38 & 5.8 & 1394 & 1390 & 1.4 & & \\
\hline 5 & Trans- $\beta$-Caryophyllene d & 1640 & 6.0 & 1431 & 1420 & 60.2 & Spicy, woody & 2 \\
\hline 6 & $\alpha$-Bergamotene ${ }^{\mathrm{t}}$ & 174 & 5.0 & 1440 & 1436 & 6.4 & Floral, woody & 2 \\
\hline 7 & $\alpha$-Humulene ${ }^{\mathrm{d}}$ & 232 & 7.0 & 1458 & 1453 & 8.6 & Floral, woody & 2 \\
\hline 8 & Allo-aromadendrene ${ }^{\mathrm{t}}$ & 15 & 5.7 & 1462 & 1460 & 0.6 & & \\
\hline 9 & $\gamma$-Muurolene ${ }^{\mathrm{t}}$ & 73 & 5.5 & 1478 & 1477 & 2.7 & Slightly woody & 16 \\
\hline 10 & Germacrene $\mathrm{D}^{\mathrm{f}}$ & 18 & 6.8 & 1481 & 1480 & 0.7 & Spicy, woody & 16 \\
\hline 11 & Bicyclogermacrene $^{t}$ & 14 & 5.8 & 1490 & 1494 & 0.5 & Woody & 16 \\
\hline 12 & $\alpha$-Muurolene ${ }^{e}$ & 14 & 6.7 & 1498 & 1499 & 0.5 & & \\
\hline 13 & $\beta$-Bisabolene ${ }^{d}$ & 30 & 6.2 & 1507 & 1508 & 1.1 & & \\
\hline 14 & Calamenene $^{\mathrm{t}}$ & 8 & 6.4 & 1515 & 1511 & 0.3 & & \\
\hline 15 & $(+)-\delta$-Cadinene ${ }^{\mathrm{d}, \mathrm{h}}$ & 52 & 3.1 & 1522 & 1524 & 1.9 & Sweet, green, refreshing & 64 \\
\hline 16 & Caryophyllene oxide $^{\mathrm{d}}$ & 5 & 6.2 & 1577 & 1578 & 0.2 & Woody & 64 \\
\hline 17 & $\tau$-Muurolol ${ }^{\mathrm{e}}$ & 4 & 6.6 & 1636 & 1622 & 0.1 & Woody & 128 \\
\hline 18 & $\delta$-Cadinol ${ }^{\mathrm{t}}$ & 25 & 6.4 & 1642 & 1631 & 0.9 & Woody & 128 \\
\hline 19 & $\alpha$-Cadinol e,f & 4 & 6.8 & 1650 & 1653 & 0.1 & Woody & 128 \\
\hline 20 & $(Z)-\alpha-$ Santalol $^{\mathrm{d}}$ & 5 & 6.2 & 1671 & 1678 & 0.2 & Woody/ Sandalwood & 128 \\
\hline 21 & Copalic acid methyl ester ${ }^{\mathrm{d}}$ & 258 & 1.1 & 2312 & - & 9.5 & & \\
\hline 22 & Kolavenic acid methyl ester ${ }^{t}$ & 2 & 7.3 & 2359 & - & $\operatorname{tr}$ & & \\
\hline 23 & $\begin{array}{l}\text { n.i. EI }{ }^{g}: m / z 318(5) \\
\text { 271(8),253(5),243(10), } \\
\text { 189(75),95(100) }\end{array}$ & 2 & 7.8 & 2422 & - & $\operatorname{tr}$ & & \\
\hline 24 & Ent- agathic acid methyl ester ${ }^{\mathrm{d}}$ & 2 & 6.8 & 2553 & - & $\operatorname{tr}$ & & \\
\hline 25 & Hydroxy-copalic acid methyl ester ${ }^{d}$ & 24 & 4.1 & 2570 & - & 0.8 & & \\
\hline 26 & Acetoxy-copalic acid methyl ester ${ }^{d}$ & 29 & 3.9 & 2634 & - & 1.0 & & \\
\hline
\end{tabular}

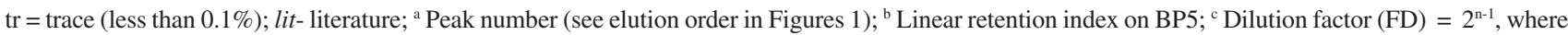
$\mathrm{n}$ is the number of dilutions (factor 2); ${ }^{\mathrm{d}}$ Co-injection with standard ; ${ }^{\mathrm{e}}$ Co-injection with marigold essential oil; ${ }^{\mathrm{f}}$ Co-injection with basil essential oil; ${ }^{g}$ Fragment ions measured in EI mode in decreasing order of relative abundance; ${ }^{\text {h }}$ Co-injected with standard in chiral $\beta$-cyclodextrine capillary column; ${ }^{t}$ tentatively identified by mass fragmentation and retention index comparison; $R S D$ - Relative standard deviation.

as C. cearensis, C. guianensis and C. duckei, C. multijuga presented a smaller amount of diterpenic acids, as evidenced by its fluidity. ${ }^{6,11,28}$ The high content of hydrocarbon and minor oxygenated sesquiterpenes almost $90 \%$ of the total composition - justifies a deeper study regarding its potential as a raw material in fragrant formulations. This excess of sesquiterpenic substances was also successfully explored by Lima and coworkers ${ }^{5}$ in the inhibition of the cellular growth in cancer.

In order to better identify the compounds responsible for its aromatic performance, five volunteers were trained on descriptive and comparative olfative analyses with woody compounds and copaiba oils to make easier the recognition of this kind of odor independently of GC-O. After statistical analysis, the judges demonstrated a preliminary tendency to better recognize the copaiba oil among other substances. Since the sampling distribution agrees with the normal distribution, the statistic $z$ is applicable. ${ }^{25}$ The test based on the difference $D$ between the two proportions rejects the hypothesis of equality at the significance level of $95 \%$, enough to characterize a greater sensitivity to copaiba oil odor. This improved capacity was probably provided by the frequency of exposition and the complexity of the sample, i.e. the richest one.

To perform GC-O C.multijuga oil was methylated with an ethereal solution of diazomethane. In a comparative olfatometric evaluation, natural and methylated oils were considered similar. Three assessors were then selected to carry out AEDA, according to their proven ability in recognizing low thresholds and time availability to perform this second part of the investigation, since this proceeding is very time-consuming..$^{29}$ The methylated sample was diluted $1: 1(\mathrm{v} / \mathrm{v})$ with $\mathrm{CH}_{2} \mathrm{Cl}_{2}$ until no odor was detected $\left(9^{\text {th }}\right.$ dilution or $\left.2^{8}\right)$ by GC-O. The screening technique pointed to a small group of significant woody compounds in the most diluted solution where odor was still perceived $\left(2^{7}\right)$. The values of the FD-factors of each odorant are described in Table 1, according to $c a$. $69 \%$ of the judgments. By GC-MS, retention index calculations and co-injection of marigold and basil essential oils these minor substances were suggested to be $\tau$-muurolol (17, $0.1 \%), \delta$-cadinol $(\mathbf{1 8}, 0.9 \%), \alpha$-cadinol $(\mathbf{1 9}, 0.1 \%)$ and (Z)- $\alpha$-santalol $(\mathbf{2 0}, 0.2 \%)$, all with FD factors of 128 
(Table 1; Figure 2). Despite their scarcity, it is important to remark that they play a significant role in the composition of the sample bouquet and confer an intense woody odor to the sample fragrance. In AEDA, they present a "block behavior". They appear and disappear simultaneously and are the most persistent group of aromatic compounds. The other active compounds were: $\delta$-cadinene $(\mathbf{1 5}, 1.9 \%$, FD 64$)$, caryophyllene oxide (16, $0.2 \%$, FD 64) and other contributors such as $\gamma$-muurolene, germacrene $\mathrm{D}$, bicyclogermacrene, $\alpha$-elemene, $\alpha$-copaene, trans- $\beta$-caryophyllene, $\alpha$-bergamotene and $\alpha$-humulene (FD factors and odor descriptions are presented in Table 1). The presence of $\delta$-cadinene (15), caryophyllene oxide (16), (Z)- $\alpha$-santalol (20), trans$\beta$-caryophyllene (5) and $\alpha$-humulene (7) were confirmed by co-injection of the standards. Concerning the sensory profile, the reference standards and the sample substances showed the same behavior when individually compared.

In order to investigate the chiral aspects of $\delta$-cadinene $((+)-\delta$-cadinene-15a; (-)- $\delta$-cadinene-15b), which has the most peculiar aroma among the active compounds in the oil, it was trapped directly from $C$. multijuga oil by adapting a piece of capillary column immersed in a cold trap at the end of the sniffing port. After washing the tube with dichloromethane, this solution (microfraction) was submitted to chiral GC-MS and showed only one peak compatible with $\delta$-cadinene fragmentation at retention time of 36.87 min. (-)- $\delta$-Cadinene (15b), obtained by acidcatalysed isomerization of $\alpha$-copaene ${ }^{27}$ showed a retention time corresponding to $35.56 \mathrm{~min}$ (RI 1558) and a similar olfactory description to the one detected in $C$. multijuga<smiles>CC1=C[C@H]2C(=C(C)CC[C@@H]2C(C)C)CC1</smiles>

$15 a$

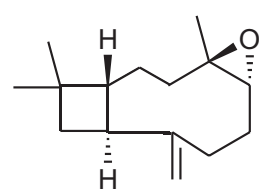

16

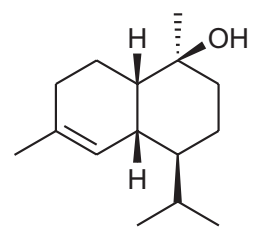

17

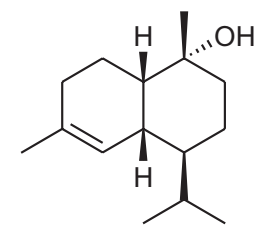

18

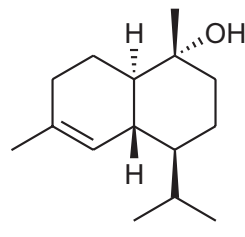

19

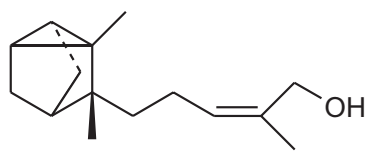

20
Figure 2. Chemical structures of the sesquiterpenes responsible for the most relevant odors in C. multijuga oil, according to AEDA, as indicated in Table 1. oil. By the co-injection of copaiba oil micro fraction and $(-)-\delta$-cadinene (15b) standard, no evidence of this enantiomer was observed in $C$. multijuga oil. The difference of $1.3 \mathrm{~min}$ in the retention times of two compounds, the identical mass spectra and the similar aroma were considered enough to suggest that (+)$\delta$-cadinene (15a) is the only enantiomer present in C.multijuga oil and has a sweet, green and refreshing aroma.

\section{Acknowledgments}

We thank the Natural Products Lab of the Chemistry Institute of the Universidade Federal do Rio de Janeiro, Dr. Margaret Essenberg, (Biochemistry and Molecular Biology Department, Oklahoma State University) and International Flavors and Fragrances - IFF, for providing the standard substances; Dr. Annibal Parracho Sant'Anna (Department of Industrial Engineering, School of Engineering, Universidade Federal Fluminense), for statistic support; CNPq, CAPES, FUJB and FAPERJ for financial support and all the volunteer students for collaborating during this project.

\section{References}

1. Ribeiro, J. E. L. S.; Hopkins, M. J. G.; Vicentini, A.; Sothers, C. A.; Costa, M. A. S.; Brito, J. M.; Martins, P. M.; Lohman, L. G.; Assunção, P. A. C. L.; Pereira, E. C.; Silva, C. F.; Mesquita, M.; Procópio, L. C.; Flora da Reserva Ducke: Guia de Identificação das Plantas Vasculares de uma Floresta TerraFirme na Amazônia Central; INPA: Manaus, 1999, p. 395.

2. http://www.abihpec.org.br/english/conteudo/material/ apresenta_\%202004_2005 .pdf, accessed in June, 2006.

3. Veiga Jr., V. F.; Pinto, A. C.; Quim. Nova 2002, 25, 273.

4. Bruneton, J.; Eléments de Phytochemie et Pharmacognosie; Lavoisier: Paris, 1987, p. 595.

5. Braga, W. F.; Rezende, C. M.; Antunes, O. A. C.; Pinto, A. C.; Phytochemistry 1998, 49, 263; Cascon, V.; Gilbert, B.; Phytochemistry 2000, 55, 773; Lima, S. R. M.; Veiga Jr., V. F.; Christo, H. B.; Pinto, A. C.; Fernandes, D. P.; Phytother. Res. 2003, 17, 1048.

6. Ferrari, M.; Monteiro, L. C. L.; Netz, D. J. A.; Rocha-Filho, P. A.; Cosmet. Toil. 2003, 118, 61.

7. Backer, W.; Chimie et Industrie (Paris) 1922, 7, 542; OseteCortina, L.; Domenech-Carbo, M. T.; J. Chromatogr. 2005, 1065, 265; Van der Werf, I. D.; Van den Berg, K. J.; Schmitt, S.; Boon, J. J.; Studies Conserv. 2000, 45, 1.

8. http://www.ibge.gov.br/home/estatistica/economia/pevs/ tabela1apevs_2001.shtm, accessed in June, 2006.

9. Alencar, J. C.; Acta Amazonica 1981, 11, 3. 
10. Turki, S.; Découverte 2000, 281, 49.

11. Aschcar, R.; Brasilessência - A Cultura do Perfume; Nova Cultural: São Paulo, 2001, pp. 106,107.

12. Rossiter, K; Chem. Rev. 1996, 96, 3201.

13. Nunzio, M. J.; Aerosol e Cosméticos 1985, 41, 9.

14. Ullrich, F.; Grosch, W.; Z. Lebensm. Unters. Forsch. 1987, 184, 277.

15. Kubickova, J.; Grosch, W.; Int. Dairy J. 1997, 7, 65.

16. Fraga, S. R. G.; Rezende, C. M.; J. Essent. Oil. Res. 2001, 13, 252.

17. Grosch, W.; Chem. Senses 2001, 26, 533.

18. Miranda E. F. J.; Nogueira, R. I.; Pontes, S. M.; Rezende, C. M.; Flavour Fragr. J. 2001, 16, 281.

19. Ferreira, V.; Pet'ka, J.; Aznar, M.; J. Agric. Food Chem. 2002, 50, 1508.

20. Alves, R. J. V.; Pinto, A. C; Costa, A. V. M.; Rezende, M. C.; J. Braz. Chem. Soc. 2005, 16, 654.

21. Kováts, E.S.Z.; Helv. Chim. Acta 1958, 41, 1915.

22. Chalchat, J. C.; Garry, R. P.; Michet, A.; Flavour Fragr. J. 1991, 6, 189; Sartoratto, A.; Machado, A. L. M.; Delarmelina, C.; Figueira, G. M.; Duarte, M. C. T.; Rehder, V. L. G.; Braz. J. Microb. 2004, 35, 275.
23. Adams, R.; Identification of Essential Oil Components by Gas Chromatography / Mass Spectroscopy; Allured Publishing Corporation: Carol Stream, 1995.

24. Pino, J. A.; Marbot, R.; Vázquez, C.; J. Agric. Food Chem. 2001, 49, 5883; Salido, S.; Altarejos, J.; Nogueras, M.; Sánchez, A.; Pannecouque, C.; Witvrouw, M.; De Clercq, E.; J. Ethnopharmacol. 2002, 81, 129.

25. Veiga, V. F.; Pinto, A. C.; de Lima, H. C.; J. Essent. Oil Res. 2006, 18, 430.

26. McLeave, J. T.; Benson, P. G.; Sincich, T.; Statistics for Business and Economy; Prentice Hall: New Jersey, 2001, p. 424.

27. Davis, G.; Essenberg, M.; Phytochemistry 1995, 39, 553.

28. Pinto, A. C.; Braga, W. F.; Rezende, C. M.; Garrido, F. M. S.; Veiga Jr, V. F.; Bergter, L.; Patitucci, M. L.; Antunes, A. O. C.; J. Braz. Chem. Soc. 2000, 11, 355.

29. Van Ruth, S. M.; Biomol. Eng. 2001, 17, 121.

Received: August 16, 2006 Web Release Date: August 9, 2007 